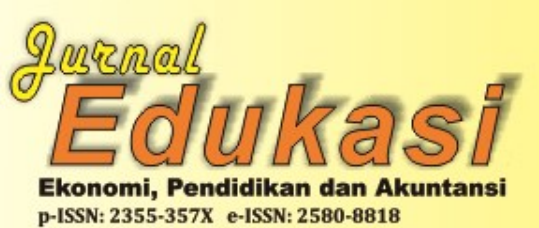

Program Studi Pendidikan Akuntansi

Fakultas Keguruan Dan Ilmu Pendidikan UNIVERSITAS GALUH CIAMIS

Jl. R. E. Martadinata No. 150 Ciamis, 46274 Jawa Barat $+62265-776787$

https://jurnal.unigal.ac.id/index.php/edukasi/article/view/4021

\title{
PENGARUH SISTEM INFORMASI AKUNTANSI PENJUALAN KREDIT TERHADAP EFEKTIVITAS PENGENDALIAN PIUTANG
}

\author{
Oleh: \\ Siti Holisoh ${ }^{1}$, Andri Indrawan ${ }^{2}$, Ade Sudarma ${ }^{3}$ \\ ${ }^{123}$ Universitas Muhammadiyah Sukabumi, Indonesia \\ holisohsiti820@gmail.com \\ Sejarah Artikel: Diterima September 2020, Disetujui Oktober 2020, Dipublikasikan November 2020
}

\begin{abstract}
ABSTRAK
Penelitian ini bertujuan untuk mengetahui pengaruh sistem infomasi akuntansi penjualan kredit terhadap efektivitas pengendalian piutang pada PT. Mandala Multifinance TBK. Populasi dan sampel pada penelitian ini adalah 45 karyawan PT. Mandala Multifinance TBK. Teknik penelitian ini menggunakan uji asumsi klasik, analisis regresi linier berganda, uji hipotesis dan uji koefisien determinasi. Teknik pengumpulan menggunakan metode dokumentasi dan wawancara.

Hasil penelitian menunjukan jumlah nilai sistem infomasi akuntansi penjualan kredit dengan koefisien regresi bertanda positif sebesar 0,997 hal tersebut menunjukkan setiap nilai sistem infomasi akuntansi penjualan kredit mengalami kenaikan satu satuan, maka akan meningkatkan efektivitas pengendalian piutang sebesar 0,997 hasil uji t (parsial) dapat diketahui bawa nilai sistem infomasi akuntansi penjualan kredit berpengaruh secara positif terhadap efektivitas pengendalian piutang pada PT. Mandala Multifinance Tbk dengan thitung 3,830 > ttabel 1,682.
\end{abstract}

Kata Kunci: Sistem Informasi Akuntansi, Penjualan Kredit.

\section{ABSTRACT}

This study aims to determine the effect of credit sales accounting information systems on the effectiveness of controlling accounts receivable at PT. Mandala Multifinance TBK. The population and sample in this study were 45 employees of PT. Mandala Multifinance TBK. This research technique uses the classic assumption test, multiple linear regression analysis, hypothesis test, and determination coefficient tests. The collection technique uses documentation and interview methods. The results showed the total value of the credit sales accounting information system with a positive regression coefficient of 0.997 , this shows that each value of the credit sales accounting information system has increased by one unit, it will increase the effectiveness of control of accounts receivable by 0.997 t-test results (partial) can be seen that the value credit sales accounting information system has a positive effect on the effectiveness of controlling accounts receivable at PT. Mandala Multifinance Tbk with t count 3,830> t table 1,682.

Keywords: Accounting Information Systems, Credit Sales.

\section{PENDAHULUAN}

Perusahaan atau organisasi didirikan oleh seseorang bisa juga didirikan oleh sekelompok badan usaha. Jenis perusahaan diantaranya perusahaan jasa, perusahaan manufaktur dan perusahaan dagang. Pada perusahaan hal yang pertama dilakukan oleh perusahaan yaitu penjualan, ada penjualan tunai dan ada juga penjualan kredit. Dengan demikian, pada perusahaan terutama yang aktivitasnya penjualan kredit sistem informasi akuntansi sangat diperlukan atau bisa dikatakan sangat dibutuhkan, seperti dalam menyediakan bukti pencatatan, bukti piutang, dan pelaporan yang memenuhi syarat atas seluruh kegiatan perusahaan, sehingga dapat disajikan informasi yang berguna bagi perusahaan. Oleh karena itu, tujuan dari sistem informasi akuntansi adalah 
untuk memproses atau mengolah data akuntansi dari sumbernya sehingga menjadi informasi akuntansi yang dibutuhkan oleh pengguna.

Menurut Mulyadi Putri dan Taufik (2017), Sistem akuntansi penjualan kredit adalah penjualan kredit yang dilakukan oleh perusahaan dengan mengirimkan barang berdasarkan pesanan yang diterima dari pembeli, dan perusahaan akan menerbitkan faktur kepada pembeli dalam jangka waktu tertentu. Kegiatan penjualan kredit ini dilakukan oleh perusahaan dengan sistem penjualan kredit, dan penjualan kredit ini memerlukan pengolahan atau pengendalian yang baik, dibandingkan dengan penjualan tunai, penjualan kredit umumnya lebih disukai oleh setiap konsumen.

Hal ini disebabkan karena penjualan secara kredit tidak langsung mengeluarkan uang dalam jumlah yang terlalu banyak, sehingga alternatif melakukan penjualan kredit peluang yang bagus bagi perusahaan untuk menarik konsumen dan meningkatan volume penjualan. Meskipun penjualan kredit lebih tinggi resikonya dibandingkan penjualan tunai sehingga perlu adanya pengawasan yang memadai dalam mengatasi tidak tertagihnya sejumlah dana dalam bentuk piutang.

Karena kegiatan yang dilaksanakan oleh perusahaan melakukan penjualan kredit, jadi dalam pengendalian penjualan terutama penjualan kredit perusahan tentunya memiliki sistem informasi akuntansi penjualan yang diatur secara baik oleh bagian sistem informasi akuntansinya agar tidak terjadi kekeliruan dan piutangnya dapat terkendali dengan baik, selain itu sistem informasi akuntansi penjualan kredit yang handal dapat menunjang efektivits pengendalian piutang.

Perusahaan yang melakukan penjualan kredit disitu akan timbul yang namanya piutang, karena ketika terjadi pengiriman barang yang sudah dipesan sebelumnya maka akan dikirim barang dan timbul piutang atas penjualan dan akan dicatat pada sistem informasi akuntansi karena telah terjadi transaksi keuangan. Kemudian piutang harus dibayar Oleh pelanggan pada saat jatuh tempo sesuai dengan apa yang telah disepakati. Ketika pelanggan membayar piutang pada saat jatuh tempo, bagian piutang akan membuat laporan pengumpulan kas. Dalam menjalankan aktivitas bisnis perusahaan, pengendalian efektivitas piutang memiliki peran tertentu dalam menunjang aktivitas bisnis perusahaan.
Masalah dalam penagihan piutang perlu adanya perhatian, agar resiko yang akan timbul dapat dihindarkan sekecil mungkin. Misalkan ada sebagian pelanggan yang tidak membayar utang mereka ketika jatuh tempo sampai pada yang gagal bayar, Ketika konsumen lalai dalam melakukan pembayaran maka akan berdampak pada perusahaan karena ada keterlambatan dalam menerima pelunasan piutang. Sehinggga perlu adanya pengendalian yang baik pada piutang yaitu untuk menghindari piutang yang tak tertagih. Dibawah ini merupakan data piutang tak tertagih tahun 2015-2019 pada PT. Mandala Multifinance Tbk :

Tabel 1:

Data piutang tak tertagih PT. Mandala Multifinance Tbk tahun 2015-2019

\begin{tabular}{rrrr} 
& $\begin{array}{c}\text { Piutang tak } \\
\text { tertagih } \\
\text { (tertunggak) }\end{array}$ & Total Piutang & $\begin{array}{c}\text { Persentasi } \\
\text { piutang tak } \\
\text { tertagih (\%) }\end{array}$ \\
\hline 2015 & $5,318,000$ & $44,154,000$ & 8,30 \\
2016 & $12,984,000$ & $58,305,000$ & 4,49 \\
2017 & $10,450,000$ & $57,800,000$ & 5,53 \\
2018 & - & - & - \\
2019 & $1,386,00$ & $26,550,000$ & 19,15 \\
\hline
\end{tabular}

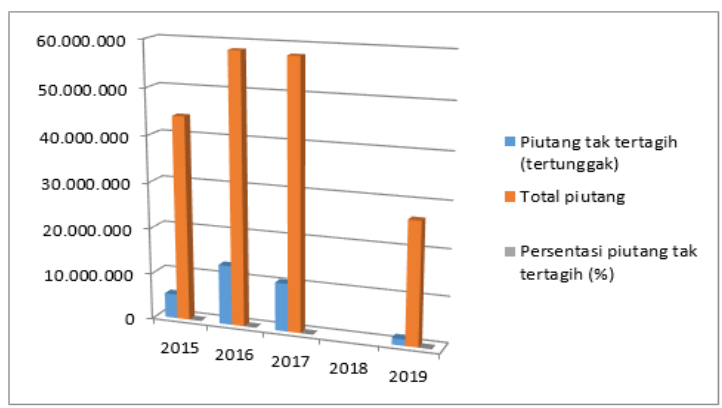

Gambar 1:

Piutang tak tertagih PT. Mandala Multifinance

Tbk cabang Surade Periode 2015-2019

Pada gambar grafik 1 piutang tak tertagih PT. Mandala Multifinance Tbk cabang Surade selama 5 tahun mengalami fluktuatif, dimana pada tahun 2015 total piutang tak tertagih sebesar Rp. 5,318,000 dari total piutang sebesar Rp. 44,154,000 diperkirakan penunggakan piutang mencapai $8,30 \%$, pada tahun 2016 meningkat sebesar Rp. 12,984,000 dari total piutang sebesar Rp. 58,305,000 dengan penunggakan piutang sebesar $4,49 \%$, kemudian pada tahun 2017 total piutang tak tertagih menjadi turun dari tahun sebelumnya yaitu Rp. $10,450,000$ dari total piutang sebesar Rp. $57,800,000$ dengan penunggakan piutang sebesar 5,53\%, ditahun 2018 tidak ada piutang tak tertagih, dan pada tahun 2019 piutang tak 
tertagih mengalami kenaikan kembali sebesar Rp. 1,386,000 dari total piutang Rp. 26,550,000 dengan penunggakan piutang tak tertagih sebesar 19,15\%. Dalam hal ini PT. Mandala Multifinance Tbk tidak berkaca pada tahun 2018, yakni dengan berhasil PT. Mandala Multifinance Tbk dapat mengatasi piutang tak tertagih dengan hasil $0 \%$, namun pada tahun 2019 mempunyai piutang tak tertagih kembali sebesar Rp. 1,386,000 dari total piutang Rp. $26,550,000$ dengan penunggakan piutang tak tertagih sebesar $19,15 \%$.

Masalah ini menjadi fenomena, seperti yang terjadi pada setiap perusahaan yang melakukan penjualan kredit. Kalaupun penjualan kredit bisa meningkatkan penjualan, perseroan masih kesulitan menagih piutang. Semakin besar volume penjualan kredit maka semakin besar pula risiko piutang tersebut. Jika tidak dikendalikan, perusahaan akan merugi.

Kendala dalam penagihan piutang bisa karena ada konsumen yang tidak mau membayar pada saat jatuh tempo dengan alasan tidak mempunyai uang untuk membayar atau karena alasan pribadi lainnya sehingga piutang tak tertagih meningkat. Supaya tidak terjadi hal yang tidak diinginkan maka harus ada pengendalian piutang yang baik agar mencapai apa yang diharapkan dan perusahaan harus bisa menjaga keamanan piutang supaya tidak timbul kerugian. Oleh karena itu, perlu untuk meningkatkan sistem informasi akuntansi penjualan kredit dan sistem informasi akuntansi penerimaan kas untuk menunjang efektivitas pengendalian piutang perusahaan.

Berdasarkan hasil penelitian terdahulu dari lima jurnal tersebut dapat dibedakan dengan penelitian yang akan diteliti oleh penulis. Dalam penelitian yang dilakukan oleh Prawiranegara (2014) menggunakan metode penelitan deskriptif analis yang berjudul peran sistem penagihan piutang dalam efektivitas pengendalian internal piutang pada PT. Bahana Cahaya Sejati (Bahana Ciamis) bagian penagihan dilakukan oleh orang ketiga yaitu bagian dari leasing maka perusahaan menagih piutang tersebut kepada leasing dengan cara surveyor leasing survey.

Penelitian terdahulu yang dilakukan oleh Nurdin (2016) menggunakan metode kuantitatif dalam penelitian yang berjudul "Pengaruh sistem informasi akuntansi penjualan terhadap efektivitas pengendalian piutang perusahaan Metro Padangsidimpuan tahun anggaran 2014" dengan hasil penelitian "terdapat pengaruh pada sistem informasi akuntansi penjualan terhadap efektivitas pengendalian piutang".

Penelitian terdahulu yang dilakukan oleh Putri dan Taufik (2017) dengan teknik pengumpulan data primer dan skunder yang berjudul "Pengaruh Sistem Informasi Akuntansi Penjualan Kredit dan Sistem Informasi Akuntansi Penerimaan Kas terhadap Efektifitas Pengendalian Piutang (Studi kasus pada Pt Tera Data Indonesia)". Penelitian serupa memang telah dilakukan sebelumnya oleh peneliti lain, namun pada perusahaan yang berbeda dan memiliki hasil yang berbeda.

Perbedaan berdasarkan Penelitian terdahulu yang dilakukan oleh Arifuddin dan Sugiono (2019) menggunakan metode kuantiatif deskriptif dengan judul penelitian "pengaruh sistem informasi akuntansi terhadap efektivitas pengendqlian piutang dan kolektabilitas piutang tak tertagih pada Bprs Bhaktii Sumekar cabang Pamekasan" dengan hasil "sistem informasi akuntansi berpengarug terhadap efektivitas pengendalin piutang dan kolektabilitas piutang tak tertagih. Nilai tersebut membuktikan bahwa Ho ditolak dan Ha diterima. Artinya ada pengaruh positif dan signifikan dari variabel sistem informai akuntansi terhadap efektivitas pengendalian pitang dan kolektabilitas piutang tak tertagih Bprs Bhakti Sumedang”.

Dalam penelitian terdahulu oleh Inuzula, Nova, dan Afrizal (2019) menggunakan metode kuantitatif dengan judul "pengaruh sistem informasi akuntansi penjualan terhadap efektivitas pengendaalian piutang Pt. Petro Ma'ar Global kabupaten Pidie Jaya" mempunyai tujuan dari hasil penelitian, untuk mengetahui dan menguji sistem informasi akuntansi penjualan mempunyai pengaruh dan peran pada efektivitas pengendalian piutang pada PT. Petro Ma'ar Global.

Berdasarkan fenomena dan perbedaan hasil penelitian sebelumnya yang telah disebutkan di atas, peneliti tertarik pada penggunaan sistem informasi akuntansi penjualan kredit, sistem informasi akuntansi pendapatan kas, dan replikasi efektivitas perusahaan perdagangan dalam mengendalikan akun. Untuk melakukan penelitian peneliti tertarik untuk mengambil judul "Pengaruh Sistem Informasi Akuntansi Penjualan Kredit terhadap Efektivitas Pengendalian Piutang" 


\section{METODE PENELITIAN}

Dalam penelitian ini yang digunakan adalah metode kuantitatif. Yang menggambarkan adanya pengaruh antara variabel yang satu dengan variabel yang lain, yaitu variabel $\mathrm{X}_{1}$ (sistem informasi akuntansi penjuaan kredit), dan Y (efektivitas pengendalian piutang). Populasi dalam penelitian berada pada satu wilayah yang berkaitan dengan masalah dalam penelitian ini. Populasi dalam penelitian ini yaitu karyawan, khususnya bagian penjualan, bagian penagihan, dan bagian penerimaan kas pada perusahaan dengan jumlah anggota populasi 45 orang. Untuk menentukan sampel pada penelitian ini, peneliti menggunakan metode non probability sampling dengan teknik purposive sampling. Pada penelitian ini peneliti mengggunakan purposive sampling. Peneliti memilih sampel hanya pada bagian penjualan, penagihan dan bagian penerimaan kas pada perusahaan.

\section{HASIL PENELITIAN DAN PEMBAHASAN}

\section{Uji Regresi Linear Sederhana}

Tabel 2:

Uji Regresi Linear Sederhana

$$
\text { Coefficients }^{\mathrm{a}}
$$

\begin{tabular}{rlrrrrrrr}
\hline & & \multicolumn{2}{c}{$\begin{array}{l}\text { Unstandardized } \\
\text { Coefficient }\end{array}$} & \multicolumn{2}{c}{$\begin{array}{c}\text { Standardized } \\
\text { Coefficients }\end{array}$} & t & Sig. & \multicolumn{2}{c}{$\begin{array}{c}\text { Collinearity } \\
\text { Statistics }\end{array}$} \\
\hline & \multicolumn{1}{c}{ B } & Std. Error & Beta & & & Tolerance & VIF \\
\hline 1 & (Constant) & 5.072 & 4.024 & & 1.261 & .214 & & \\
\hline & SIA Penjualan Kredit & .997 & .260 & .511 & 3.830 & .000 & .360 & 2.774 \\
\hline
\end{tabular}

Diketahui persamaan regresi adalah sebagai berikut:

$$
\mathrm{Y}=\alpha+\beta 1 . \mathrm{X} 1+\varepsilon
$$

Dengan mengacu pada persamaan regresi sederhana diatas, maka dapat dihasilkan persamaan regresi sesuai dengan tabel adalah sebagai berikut:

$$
\mathrm{Y}=(5,072)+(0,997) \mathrm{X} 1+\varepsilon
$$

\section{Keterangan :}

Y : Efektivitas Pengendalian Piutang

$\mathrm{X} 1$ : Sistem Informasi Akuntansi Penjualan Kredit

- Koefisien konstanta $\alpha=5,072$ bernilai positif menyatakan bahwa dengan mengasumsikan ketiadaan variabel Sistem Informasi Akuntansi Penjualan Kredit $\left(\mathrm{X}_{1}\right)$ variabel tersebut dinyatakan nilainya 0 , maka efektivitas pengendalian piutang $(\mathrm{Y})$ mengalami kenaikan sebesar 5,072.

- Koefisien $b_{1}=0,997$ bernilai positif menyatakan bahwa dengan mengasumsi ketiadaan variabel independen lainnya maka apabila sistem informasi akuntansi penjualan kreditnya ditingkatkan 1 satuan, maka efektivitas pengendalian piutang akan naik sebesar 0,997.

Berdasarkan persamaan regresi tersebut, dapat diketahui bahwa koefisien intercept dari persamaan diatas adalah sebesar 5,072 yang mengandung pengertian bahwa pada saat tingkat sistem informasi akuntansi penjualan kredit $\left(\mathrm{X}_{1}\right)$, Dari persamaan diatas juga dapat diketahui jika sistem informasi akuntansi penjualan kredit (X1) naik, maka efektivitas pengendalian piutang akan naik sebesar 0,997.

\section{Uji Parsial (Uji t)}

Berdasarkan tabel 2 diketahui nilai dari $t_{\text {hitung. Untuk selanjutnya dibandingkan dengan }}$ nilai tabel dengan didasarkan pada $\mathrm{dk}=(\mathrm{n}-\mathrm{k}-1)$ dan taraf kesalahan yang ditetapkan sebesar $5 \%$, jadi $\mathrm{dk}=45-2-1=42$ sehingga diperoleh $\mathrm{T}_{\text {tabel }}=2.01808$. Berdasarkan pada tabel 2 maka untuk variabel sistem informasi akuntansi penjualan kredit $\left(\mathrm{X}_{1}\right)$ diketahui bahwa derajat signifikannya $0,000<0,05$ yang artinya $\mathrm{H}_{a 1}$ diterima dan $\mathrm{H}_{\mathrm{o} 1}$ ditolak dimana sistem informasi akuntansi penjualan kredit $\left(\mathrm{X}_{1}\right)$ secara parsial memberikan pengaruh nyata terhadap terhadap efektivitas pengendalian piutang (Y). 


\section{Uji Koefisien Determinasi $\left(\mathbf{R}^{\mathbf{2}}\right)$}

Tabel 3:

Uji Koefisien Determinasi $\left(\mathrm{R}^{2}\right)$ Model Summary

\begin{tabular}{|c|c|c|c|c|}
\hline \multicolumn{5}{|c|}{ Model Summary } \\
\hline Model & $\mathrm{R}$ & $\mathrm{R}_{\text {Square }}$ & $\begin{array}{l}\text { Adjusted } \\
\text { R Square }\end{array}$ & $\begin{array}{l}\text { Std. } \\
\text { Error of } \\
\text { the } \\
\text { Estimate }\end{array}$ \\
\hline 1 & $.855^{\mathrm{a}}$ & .731 & .718 & 3.877 \\
\hline
\end{tabular}

Dari tabel diatas diketahui $\mathrm{r}^{2}$ ( $R$ Square) dalam penelitian ini adalah 0,731 atau $73,1 \%$ yang artinya sumbangan pengaruh dari variabel independen yaitu hanya $73,1 \%$ sedangkan sisanya sebesar $26,9 \%$ dipengaruhi oleh faktor lain yang tidak diteliti.

Untuk mengetahui pengaruh variabel sistem informasi akuntansi penjualan kredit (X1) terhadap efektivitas pengendalian piutang (Y), dilakukan perhitungan koefisien determinasi dengan rumus sebagai berikut:

$$
\mathrm{Kd}=\mathrm{R}^{2} \times 100 \%
$$

Dimana:

Kd: Koefisien determinasi

R: Koefisien korelasi

Sehingga diketahui koefisien determinasinya adalah sebagai berikut

$\mathrm{Kd}=\mathrm{R}^{2} \times 100 \%$

$\mathrm{Kd}=(0,855)^{2} \times 100 \%$

$\mathrm{Kd}=0,731 \times 100 \%$

$\mathrm{Kd}=73,1 \%$

Adapun kriteria untuk koefisien determinasi adalah sebagai berikut:

1. Jika kd mendekati 0, maka pengaruh variabel sistem informasi akuntansi penjualan kredit $\left(\mathrm{X}_{1}\right)$ terhadap efektivitas pengendalian piutang $(\mathrm{Y})$ lemh.

2. Jika kd mendekati 1, maka pengaruh variabel sistem informasi akuntansi penjualan kredit $\left(\mathrm{X}_{1}\right)$ terhadap efektivitas pengendalian piutang $(\mathrm{Y})$ kuat.

Berdasarkan perhitungan koefisien determinasi, diketahui bahwa nilai $\mathrm{KD}=$ $73,1 \%$, maka dapat disimpulkan bahwa pengaruh sistem informasi akuntansi penjualan kredit terhadap efektivitas pengendalian piutang termasuk dalam kriteria kuat.

\section{Pembahasan}

Prosedur penjualan kredit PT. Mandala multiple financial Tbk. Diantaranya prosedur order penjualan, prosedur persetujuan kredit, prosedur pengiriman, prosedur invoice, prosedur peningkatan pencatatan piutang dan prosedur distribusi penjualan. Manfaat dari proses penjualan kredit adalah: menstandarkan cara pegawai menyelesaikan tugas, mengurangi tingkat kesalahan, meningkatkan efisiensi dan efisiensi pelaksanaan tugas, serta memberikan informasi tentang beban kerja yang akan dilakukan pegawai dalam melaksanakan tugasnya. Prosedur penjualan kredit yang diterapkan pada PT. Mandala Multifinance Tbk. adalah sebagai berikut:

a. Prosedur Permintaan Informasi Barang

Aktivitas penjualan dari suatu perusahaan biasanya dimulai dari prosedur permintaan informasi barang atau jasa yang dimiliki perusahaan dari konsumen. Apabila ada konsumen yang melakukan hal ini maka perusahaan akan mengirimkan daftar barang yang dimilikinya beserta rincian harga, syarat pembayaran dan kebijakan-kebijakan lainnya kepada konsumen. Berdasarkan informasi inilah konsumen selanjutnya akan melakukan pemesanan barang kepada perusahaan.

b. Prosedur Penerimaan Pesanan Penjualan (order penjualan)

Setelah proses pengecekan terhadap Sales Order selesai tahap selanjutnya adalah dilakukan pengecekan terhadap persediaan barang dan harga yang diminta oleh konsumen. Apabila jumlah persediaan barang dan harga yang diminta oleh konsumen. Jika tingkat persediaan dan harga yang diminta oleh pelanggan sudah sesuai maka perusahaan dapat melanjutkan ke aktivitas selanjutnya yaitu proses penjualan faktur, tetapi jika pesanan tidak disetujui karena persediaan yang tidak mencukupi atau harga yang tidak dapat dinegosiasikan, biasanya perusahaan akan mengembalikan pelanggan atau pelanggan yang dikirim Surat pesanan. Permintaan untuk mengubah pesanan berdasarkan inventaris yang ada.

c. Prosedur Persetujuan Kredit

Prosedur persetujuan kredit pada PT. Mandala Multifinance Tbk. dimulai konsumen akan mengirimkan order penjualan perusahaan berdasarkan sejumlah informasi yang dipesannya pada perusahaan berdasarkan sejumlah informasi yang sudah diperoleh sebelumnya melalui surat order penjualan. Berdasarkan aktivitas ini bagian pejualan akan melakukan pengecekan terhadap identitas konsumen/pelanggan. Biasanya untuk pelanggan yang terbiasa melakukan aktivitas jual beli dengan perusahaan, perusahaan sudah 
mencatat pelanggan tersebut. Pengecekan tersebut dilakukan dengan maksud agar perusahaan dapat mengetahui apakah pelanggan yang melakukan order penjualan tersebut layak diberikan piutang atau tidak, karena untuk pelanggan yang masih mempunyai sisa tunggakan perusahaan dapat melakukan kebijakan untuk tidak memberikan penjualan secara kredit terlebih dahulu.

\section{d. Prosedur Pengambilan Barang/persediaan}

Apabila bagian penjualan sudah menyetujuan pesanan penjualan yang diminta oleh customer, bagian penjualan selanjutnya akan meminta sejumlah barang yang aan dikirimkan kepada konsumen dengan menyerahkan dokumen persetujuan ke bagian gudang barang. Jadi, bagian gudang barang jadi berdasarkan dokumen persetujuan kredit tersebut selanjutnya akan mempersiapkan pengambilan barang dengan memuat dokumen daftar pengambilan barang, selanjutnya bagian gudang akan mencocokkan dokumen persetujuan kredit dengan dokumen sales order dan data persediaan yang disimpan dalam data base pesanan dan persediaan perusahaan, apabila kedua data tersebut telah sesuai maka bagian gudang barang jadi akan mengeluarkan persediaan sejumlah yang tertera dalam dokumendokumen tersebut (sales order, persetujuan kredit dan daftar pengambilan barang) ke bagian pengiriman barang beserta tembusan daftar pengambilan barangnya.

\section{e. Prosedur Pengiriman Barang}

Setelah menerima barang dan daftar pengiriman barang dari bagian gudang barang jadi, bagian pengiriman melakukan aktivitas pengepakan barang dan membuat daftar pengepakan barang selanjutnya bagian pengiriman mengirimkan barang yang dipesan kepada customer.

f. Prosedur Penagihan

Setelah barang sampai ke tangan konsumen dan disepakatinya sejumlah tagihan yang disetujui, bagian penagihan berdasarkan jumlah tagihan yang jatuh tempo akan melakukan penagihan kepada konsumen dengan terlebih dahulu mengecek daftar penagihan yang telah disepakati oleh konsumen dalam database pesanan apabila sudah sesuai langkah selanjutnya bagian penagihan akan mempersiapkan faktur penjualan yang akan langsung ditagikan kepada konsumen. Selain aktivitas penagihan bagian penagihan juga menyiapkan transaksi penjualan kredit secara periodic dengan membuat invoice atau faktur penjualan yang akan diserahkan kepada bagian buku besar.

Dari data sebelumnya diketahui bahwa hipotesis yang diterima ialah Hal sedangkan Ho1 ditolak dimana menunjukkan bahwa sistem informasi akuntansi penjualan kredit berpengaruh terhadap efektivitas pengendalian piutang. Dapat diketahui bahwa besarnya $t_{\text {hitung }}$ adalah 3,830 sedangkan nilai $t_{\text {tabel }}$ adalah 1,682 kemudian nilai signifikansinya adalah 0,000 dengan taraf signifikan 0,05 sehingga $t_{\text {hitung }}>$ $\mathrm{t}_{\text {tabel }}(3,830>1,682)$ dan sig. $0,000<0,005$. Dengan demikian variabel sistem informasi akuntansi penjualan kredit secara parsial berpengaruh terhadap efektivitas pengendalian piutang pada PT. Mandala Multifinance Tbk.

Dengan membuktikan pengaruh sistem informasi akuntansi penjualan kredit terhadap efektivitas pengendalian piutang, hal ini membuktikan teori Hastoni (2004). Prosedur penjualan ". Aktivitas penjualan kredit membutuhkan penanganan atau pengendalian yang baik, dibandingkan dengan penjualan tunai, setiap konsumen lebih memilih penjualan kredit. Hal ini disebabkan karena penjualan secara kredit tidak langsung mengeluarkan uang dalam jumlah yang terlalu banyak, sehingga alternatif melakukan penjualan kredit peluang yang bagus bagi perusahaan untuk menarik konsumen dan meningkatan volume penjualan. Meskipun penjualan kredit lebih tinggi resikonya dibandingkan penjualan tunai sehingga perlu adanya pengawasan yang memadai dalam mengatasi tidak tertagihnya sejumlah dana dalam bentuk piutang.

Permasalahan yang terjadi pada PT. Mandala Multifinance Tbk yakni mengalami kendala dalam penagihan piutang. Hal tersebut berasal dari faktor pembeli yang melakukaan penjualan secara over credit dan yang berpindah tempat tinggal tanpa mengkonfirmasi kepada perusahaan, selain itu masalah yang umum dihadapi PT. Mandala Multifinance Tbk ialah penagihan piutang yang telah jatuh tempo tidak selalu dapat diselesaikan seluruhnya. Hal ini tentu menjadi perhatian penting bagi PT. Mandala Multifinance Tbk untuk lebih mengawasi tidak tertagihnya dana dalam bentuk piutang. Dengan meningkatnya penjualan maka pendapatan dan laba perusahaan akan meningkat, namun karena bertambahnya piutang tak tertagih maka kerugian perusahaan juga akan bertambah. (Arifuddin dan Sugiono, 2019). 
Karena kegiatan yang dilakukan oleh PT. Mandala Multifinance Tbk melakukan penjualan kredit, jadi dalam pengendalian penjualan terutama penjualan kredit tentunya memiliki sistem informasi akuntansi penjualan yang diatur secara baik oleh bagian sistem informasi akuntansinya agar tidak terjadi kekeliruan dan piutangnya dapat terkendali dengan baik, selain itu sistem informasi akuntansi penjualan kredit yang handal dapat menunjang efektivitas pengendalian piutang.

Hasil penelitian ini juga sejalan dengan penelitian yang dilakukan oleh Prawiranegara (2014), yaitu sistem penagihan piutang berperan aktif dalam meningkatkan efektivitas pengendalian internal PT atas piutang dagang. True Light Bahana. Oleh karena itu, sistem penagihan piutang PT. Bahana Cahaya Sejati (Bahana Ciamis) membantu manajemen dalam meningkatkan efektivitas pengendalian internal pada piutang. Hal ini terlihat dari penerapan sistem penagihan piutang yang mendukung penerapan pengendalian internal yang memadai terhadap piutang.

Penelitian yang dilakukan oleh Nurdin (2016) pada seluruh karyawan perusahaan Metro Padangsidimpuan dengan jumlah sampel 35 orang, menyebutkan bahwa terdapat pengaruh antara sistem informasi akuntansi penjualan terhadap efektivitas pengendalian piutang. Nurdin (2016) Terungkap juga bahwa sumber daya yang dimiliki perusahaan dijual melalui kredit, sehingga perlu adanya proses atau pengendalian efisiensi operasional perusahaan karena jika piutang terlalu banyak kemungkinan tidak terpulihkan lebih besar, sehingga perlu dilakukan penyesuaian. Piutang dikendalikan untuk menghindari akun yang tidak tertagih. Dalam rangka pengendalian piutang terdapat hubungan antara sistem informasi akuntansi penjualan, dan terdapat hubungan yang saling mendukung antara sistem informasi penjualan dan pengendalian piutang.

Hal tersebut senada dengan penelitian terdahulu yang dilakukan oleh Inuzula, Nova, dan Afrizal (2019) dan Putri dan Aziz (2017) menggunakan metode kuantitatif yaitu terdapat sistem informasi akuntansi penjualan mempunyai pengaruh dan peran pada efektivitas pengendalian piutang.

Dari hasil analisis data dan pembahasan, dapat ditarik kesimpulan bahwa sistem informasi akuntansi penjualan kredit harus dikelola secara baik oleh bagian sistem informasi akuntansinya agar tidak terjadi kekeliruan dan piutangnya dapat terkendali dengan baik, karena sistem informasi akuntansi penjualan kredit yang handal dapat menunjang efektivitas pengendalian piutang.

\section{PENUTUP}

Berdasarkan hasil penelitian dan pembahasan mengenai pengaruh sistem informasi akuntansi penjualan kredit terhadap efektivitas pengendalian piutang PT. Dapat disimpulkan bahwa Mandala Multifinance Tbk adalah sistem informasi akuntansi penjualan kredit mempunyai pengaruh penting terhadap efektivitas pengendalian piutang pada PT. Mandala Multifinance Tbk, hal ini menunjukkan bahwa sistem informasi akuntansi penjualan kredit memegang peranan penting dalam pengendalian efektivitas piutang. Oleh karena itu, dalam hal ini peneliti dapat memberikan saran sebagai berikut:

1) Bagi PT. Mandala Multifinance tbk agar perlu adanya peningkatan pemahaman tentang sistem informasi akuntansi oleh karyawan, mengadakan program-program pendidikan dan pelatihan untuk para karyawan yang sesuai dengan bidangnya sehingga kemampuan dan keterampilan karyawan tetap terpelihara dan dapat meningkatkan kemajuan perusahaan

2) Perlu adanya evaluasi atas kebijakan manajemen dalam pemberian kredit kepada pelanggan dan kebijakan jadwal dalam penagihan piutang dan pemberian sanksi tegas kepada pelanggan yang menunggak melebihi batas jatuh tempo agar tidak terjadi piutang yang bertumpuk.

3) Bagi akademis, penelitian ini diharapkan dapat menjadi kajian ilmu untuk memahami teori dan wawasan ilmiah dalam pemahaman bidang Ilmu Akuntansi yang berkaitan dengan studi sistem informasi akuntansi penjualan kredit dan efektivitas pengendalian piutang. Dikarenakan adanya keterbatasan peneliti dalam melakukan penelitian ini, yakni sampel yang dilakukan pada penelitian ini hanya dilakukan pada PT. Mandala Multifinance tbk, variabel yang digunakan dalam penelitian ini belum mewakili semua faktor-faktor yang mempengaruhi efektivitas pengendalian piutang. Untuk itu peneliti menyarankan kepada penelitian selanjutnya yang berhubungan dengan sistem informasi akuntansi penjualan kredit dan efektivitas pengendalian piutang untuk dapat 
melakukan penelitian di sektor lainnya sehingga dapat membandingkan hasil penelitian dengan sebelumnya. Selain itu pengembangan variabel juga perlu dilakukan untuk mengetahui faktor-faktor lain yang mempengaruhi efektivitas pengendalian piutang.

\section{DAFTAR PUSTAKA}

Arifuddin dan Agus Sugiono. (2019). Pengaruh Sistem Informasi Akuntansi Terhadap Efektivitas Pengendalian Piutang dan Kolektabilitas Piutang Tak Tertagih pada Bprs Bhakti Sumekar Cabang Pamekasan. Jurnal Akuntansi Dan Investasi Vol 3, No 1.

Hastoni. (2004). Pengaruh sistem dan prosedur penjualan dalam menunjang efektivitas intern piutang. Jurnal Ilmiah Ranggading, 4(2)

Inuzula, Lakharis. Nova. dan Afrizal. (2019). Pengaruh Sistem Informasi Akuntansi Penjualan Terhadap Efektivitas Pengendalian Piutang PT. Petro Ma'ar Global Kabupaten Pidie Jaya. Jurnal Kebangsaan Vol. 8 No. 16. 2089-5917.

Nurdin, A. (2016). Pengaruh Sistem Informasi
Akuntansi Penjualan Terhadap

Efektivitas Pengendalian Piutang

Perusahaan Metro Padangsidimpuan

Tahun Anggaran 2014. NUSANTARA:

Jurnal Ilmu Pengetahuan Sosial, 1(1).

Putri, Dwi Astuty Dharma dan Taufik Aziz. (2017). Pengaruh Sistem Informasi Akuntansi Penjualan Kredit Dan Sistem Informasi Akuntansi Penerimaan Kas Terhadap Efektifitas Pengendalian Piutang (Studi Kasus Pada PT Tera Data Indonesia). Jurnal Proaksi. Vol 4. No. 1.

Prawiranegara, Benny. (2014). Peranan Sistem Penagihan Piutang Dalam Meningkatkan Efektivitas Pengendalian Intern Piutang. Jurnal Wawasan Dan Riset Akuntansi Vol. 2, No. 1, 2355-7478. 